\title{
Y ield of aerobic rice affected by high temperature stress during summer season -A study from red and laterite zone of West Bengal, India
}

\author{
K.J ana*, G. K. M allick and S. G hosh \\ Rice Research Station (Govt. of West Bengal), Bankura - 722101 (West Bengal), INDIA \\ *Corresponding author. E-mail: kjanarrs@gmail.com
}

Received: August 5, 2013; Revised received: September 9, 2013; Accepted: September 15, 2013

Abstract: Field experiment on the performance of aerobic direct seeded rice (ADSR) under red and laterite zone of West Bengal was conducted at Rice Research Station, Bankura, West Bengal, India during summer season, 2012. The experimental soil was sandy loam with acidic in nature $(\mathrm{pH}: 5.2)$. The results exhibited that the grain yield $(1 \mathrm{t}$ $\mathrm{ha}^{-1}$ ) of rice in aerobic situation was low. This might be due to high atmospheric temperature during flowering period, which results in poor grain setting in panicle and most of them became chaffy due to spikelet sterility. Ultimately, it produced low grain yield of rice in aerobic situation during summer season due to high temperature at flowering period, grain formation and grain ripening stages. Thus, aerobic rice system of cultivation needed good management practices.

Keywords: Aerobic rice, High temperature, Low yield, Spikelet sterility

\section{INTRODUCTION}

Rice (O ryza sativa L.) is an important cereals crop and grown across the world. By the end of $21^{\text {st }}$ Century, the earth's climate is predicted to warm by an average of 2$4^{\circ} \mathrm{C}$ (IPCC, 2007), due to anthropogenic and natural factors (Eitzinger et al., 2010). Rice cultivation is a water intensive enterprise. However, lowland rice fields have relatively high water requirements and their sustainability is threatened by increasing water shortages (Bouman and Tuong, 2001). Aerobic rice system is a new way of growing rice that needs less water than low land rice. It is grown like an upland crop in soil that is not puddled, non-flooded or saturated. It is a sustainable rice production methodology for immediate future to address water scarcity and environmental safety arising due to global warming. Most rice is currently grown in regions where current temperatures are already close to optimum for rice production. Therefore, any further increase in mean temperature or of short episodes of high temperature during sensitive stages may be supra-optimal and reduce grain yield. Yields of rice have been estimated to be reduced by $41 \%$ by the end of the $21^{\text {st }}$ Century (Ceccarelli et al., 2010)

But, the incidence of very variable yield and complete yield failure were observed in dry season in the Philippines (Kreye et al., 2007). The optimum temperature for the normal development of rice is ranges from 27 to $32^{\circ} \mathrm{C}$ (Yin et al., 1996). Very high temperature is a threat to rice production, particularly during flowering period. Temperature higher than the optimum induced floret sterility and thus caused decreased rice yield (Nakagawa et al., 2003). The impact of high temperature at night is more devastating than day-time or mean daily temperature. Among the physiological growth stages of rice, booting and flowering stages are most sensitive to high temperature, which may sometimes lead to complete sterility (Shah et al., 2011). Flowering (anthesis and fertilization) and to a lesser extent the preceding stage booting are considered to be the stages of development most susceptible to temperature in rice (Farrell et al., 2006). Humidity at increased temperature also plays an important role in increasing the spikelet sterility (Shah et al., 2011).

Keeping above in view, the present investigation was undertaken to study the package of practices and feasibility of aerobic rice system in aerobic situation during summer season.

\section{MATERIALS AND METHODS}

The experiment was laid out in observational plots with three replications. Total number of plots $\left(\mathrm{P}_{1}, \mathrm{P}_{2}, \mathrm{P}_{3}\right.$ and $\mathrm{P}_{4}$ ) was four in each replication and total number of plots was twelve in this experiment. The plot size was $10 \times 8 \mathrm{~m}$. The rice variety was Puspa (IET 17509). The date of direct sowing in un-puddled field was $7^{\text {th }}$ February, 2012. Direct seeding of dry treated seed (carbendazim @ 2g per kg seed) with spacing of 20 X 15 $\mathrm{cm}$ was done. The recommended fertilizer dose was $\mathrm{N}$, $\mathrm{P}_{2} \mathrm{O}_{5}, \mathrm{~K}_{2} \mathrm{O} @ 80,40,40 \mathrm{~kg} \mathrm{ha}^{-1} .25 \%$ of recommended dose of nitrogen, full dose of phosphorus, $75 \%$ of potash 
and zinc sulphate $\left(\mathrm{ZnSO}_{4}\right) @ 20 \mathrm{~kg} \mathrm{ha}^{-1}$ were applied as basal. Remaining dose of nitrogen in two splits was applied. 50\% nitrogen at active tillering stage and 25\% nitrogen along with 25\% Potash at Panicle initiation stage were applied. Harvesting was done on 04.06.2012.

Need based seven numbers of irrigations were applied according to physiological growth stages of rice plant and observing soil condition, particularly when hair line cracks developed on the soil surface. To control rice gundhibug during milky stage and stem borer, carbosulfan 6G and carbofuran 3G was applied at 10 days interval.

Plant height (from ground level to the tip of the flag leaf) was taken at ripening stage based on randomly selected ten plants. The $5 \mathrm{~m}^{2}$ area in the middle of each plot was harvested for recording grain yield. Ten rice hills outside the harvested area were selected and harvested separately for recording yield parameters, viz. number of tillers per hill, length of panicle and panicle weight etc. Meteorological data (Tables 2 and 3) was taken from State Agricultural Farm (SAF), Office of the Assistant Director of Agriculture, Bankura, West Bengal.

The characteristics of red and laterite soils are poor in calcium, organic matter content, available phosphate and in bases. Land is undulating and has many tiny rivulets. These rivulets are dry except during rainy season. The upland soils are mostly eroded red-gravelly with a very low water holding capacity. Crust formation in the upland soils is serious problem. The top soils are poor in iron due to leaching and accumulation takes places in deep subsoil. This experiment was conducted in upland. The texture of experimental soil was sandy loam with acidic in nature (pH: 5.2) and $0.13 \mathrm{ds} \mathrm{m}^{-1} \mathrm{EC}$,
$0.51 \%$ organic carbon, $33 \mathrm{~kg} \mathrm{ha}^{-1}$ available $\mathrm{P}_{2} \mathrm{O}_{5}, 183 \mathrm{~kg}$ $\mathrm{ha}^{-1}$ available $\mathrm{K}$.

\section{RESULTS AND DISCUSSION}

It was revealed from the experiment that good crop stand was obtained with Puspa (IET 17509) variety. The average value of plant height was $91.6 \mathrm{~cm}$. The average value of number of tillers hill ${ }^{-1}$ was 16.8 . Low grain yield $\left(1 \mathrm{t} \mathrm{ha}^{-1}\right)$ was resulted from this experiment. The average value of number of unfilled grains per panicle was 81 (Table 1). High atmospheric temperature was prevailed during flowering period, grain formation and grain ripening stages. As a result of which, more number of grains in a panicle became chaffy and ultimately produced low grain yield of aerobic rice. It was mainly due to floret sterility. As very hot wave and dry weather conditions prevailed during the end of April to May, 2012 (Table 2 and 3), the condition improved the spikelet sterility. The similar trend was also noticed by Nakagawa et al. (2003). Exposure to $41^{\circ} \mathrm{C}$ for 4 hour at flowering caused irreversible damaged and plants became completely sterile (IRRI, 1976). The low aerobic rice grain yield was due to prevail of high atmospheric temperature during the study that affected almost all the growth stages of rice from emergence to ripening and harvesting. This was agreed with findings of Yin et al. (1996) and Shah et al. (2011). Spikelet sterility was greatly increased at temperature higher than $35^{\circ} \mathrm{C}$ (Matsui et al., 1997a). It was also observed that soil became dry and hard within a very short period after application of irrigation. The soils of red and laterite areas were sandy loams (very light textured), low in water holding capacity, poor in organic matter content and presence of tiny rivulets.

Table 1. Grain yield and ancillary characters of rice in aerobic situation during summer, 2012.

\begin{tabular}{|c|c|c|c|c|c|c|c|c|}
\hline Plot & $\begin{array}{l}\text { Plant } \\
\text { height } \\
(\mathrm{cm})\end{array}$ & $\begin{array}{l}\text { No. of } \\
\text { effective } \\
\text { tillers } \\
\mathrm{m}^{-2}\end{array}$ & $\begin{array}{c}\text { No. } \\
\text { tillers } \\
\text { per hill }\end{array}$ & $\begin{array}{c}\text { Panicle } \\
\text { length } \\
(\mathrm{cm})\end{array}$ & $\begin{array}{c}\text { Panicle } \\
\text { weight } \\
\text { (g) }\end{array}$ & $\begin{array}{l}\text { No. of } \\
\text { filled } \\
\text { grains } \\
\text { panicle-1 }\end{array}$ & $\begin{array}{l}\text { No. of } \\
\text { Unfilled } \\
\text { grains } \\
\text { panicle }\end{array}$ & $\begin{array}{l}\text { Grain } \\
\text { yield } \\
\left(\text { t ha }^{-1}\right)\end{array}$ \\
\hline $\mathrm{P}_{1}$ & 87.2 & 354.5 & 14.5 & 21.2 & 0.98 & 35.6 & 68.2 & 0.88 \\
\hline $\mathrm{P}_{2}$ & 95.8 & 372.1 & 18.7 & 23.7 & 0.91 & 26.7 & 86.1 & 0.95 \\
\hline $\mathrm{P}_{3}$ & 92.0 & 402.8 & 21.5 & 22.6 & 1.05 & 38.5 & 90.5 & 1.08 \\
\hline $\mathrm{P}_{4}$ & 91.4 & 325.6 & 12.6 & 21.4 & 1.10 & 40.2 & 79.3 & 1.12 \\
\hline A ver age & 91.6 & 363.7 & 16.8 & 22.2 & 1.01 & 35.2 & 81.0 & 1.00 \\
\hline \multicolumn{2}{|l|}{ Months } & \multicolumn{2}{|c|}{ M ax. temp. (Av.) } & \multicolumn{2}{|c|}{ Min. temp. (Av.) } & Rainfall (mm) & $\begin{array}{c}\text { Tota } \\
r\end{array}$ & $\begin{array}{l}\text { number of } \\
\text { ny days }\end{array}$ \\
\hline \multicolumn{2}{|c|}{ February, 2012} & \multicolumn{2}{|c|}{$30.21^{\circ} \mathrm{C}$} & \multicolumn{2}{|c|}{$18.5^{\circ} \mathrm{C}$} & 11.9 & & 2 \\
\hline \multicolumn{2}{|c|}{ March, 2012} & \multicolumn{2}{|c|}{$36.53{ }^{0} \mathrm{C}$} & \multicolumn{2}{|c|}{$19.66^{\circ} \mathrm{C}$} & 13.6 & & 1 \\
\hline \multicolumn{2}{|c|}{ April, 2012} & \multicolumn{2}{|c|}{$41.54{ }^{0} \mathrm{C}$} & \multicolumn{2}{|c|}{$23.64{ }^{0} \mathrm{C}$} & 82.1 & & 5 \\
\hline \multicolumn{2}{|c|}{ May, 2012} & \multicolumn{2}{|c|}{$40.41^{0} \mathrm{C}$} & \multicolumn{2}{|c|}{$24.70{ }^{\circ} \mathrm{C}$} & 61.5 & & 5 \\
\hline \multicolumn{2}{|c|}{ June, 2012} & \multicolumn{2}{|c|}{$38.70{ }^{0} \mathrm{C}$} & \multicolumn{2}{|c|}{$27.39{ }^{0} \mathrm{C}$} & 123.4 & & 8 \\
\hline
\end{tabular}

High temperature coincide with anthesis and flowering period at $1^{\text {st }}$ and $2^{\text {nd }}$ week of May, 2012

(Source: State Agricultural Farm, Bankura, West Bengal) 
Table 3. Maximum and minimum temperature during the month of May, 2012 during the study.

\begin{tabular}{ccc}
\hline Dates & Max. Temp. (Av.) & Min. Temp. (Av.) \\
\hline 13.05 .2012 & $39.5{ }^{\circ} \mathrm{C}$ & $25.3{ }^{\circ} \mathrm{C}$ \\
14.05 .2012 & $41.0{ }^{\circ} \mathrm{C}$ & $27.5{ }^{\circ} \mathrm{C}$ \\
15.05 .2012 & $44.0{ }^{\circ} \mathrm{C}$ & $29.2{ }^{\circ} \mathrm{C}$ \\
16.05 .2012 & $43.0{ }^{\circ} \mathrm{C}$ & $26.2{ }^{\circ} \mathrm{C}$ \\
17.05 .2012 & $44.0{ }^{\circ} \mathrm{C}$ & $28.2{ }^{\circ} \mathrm{C}$ \\
18.05 .2012 & $45.5{ }^{\circ} \mathrm{C}$ & $28.2{ }^{\circ} \mathrm{C}$ \\
24.05 .2012 & $44.0{ }^{\circ} \mathrm{C}$ & $27.7{ }^{\circ} \mathrm{C}$ \\
25.05 .2012 & $46.0{ }^{\circ} \mathrm{C}$ & $29.6{ }^{\circ} \mathrm{C}$ \\
26.05 .2012 & $46.0{ }^{\circ} \mathrm{C}$ & $27.0{ }^{\circ} \mathrm{C}$ \\
\hline
\end{tabular}

High temperature coincide with grain formation and grain ripening stages of rice plant

(Source: State Agricultural Farm, Bankura, West Bengal)

\section{Conclusion}

The present study concluded that low grain yield of rice in aerobic situation during summer season, 2012 was mainly due to high temperature during flowering period, grain formation and grain ripening stages. Spikelet sterility at high temperature was the main reason for lower grain yield during summer season.

\section{ACKNOWLEDGEMENTS}

The authors would like to thanks Dr. P. K. Maity, Chief Agronomist, FCRS, Burdwan; Mr. S. R. Patra, Joint Director of Agriculture (Research); Dr. P. Bhattacharyay, Director of Agriculture, Writers' Building, Klokata and Prof. B. K. Mandal, retired Professor and former Head and Prof. P. Bandyopadhyay, Dr. K. Brahmachari, Department of Agronomy, Bidhan Chandra Krishi Viswavidyalay, Mohanpur, Nadia, West Bengal, India for their valuable guidance and encouragement during the period of this research programme.

\section{REFERENCES}

Bouma, B. A. M. and Tuong, T. P. (2001). Field water management to save water and increase its productivity in irrigated rice. Agricultural Water M anagement 49 (1): 1130.

Ceccarelli, S., Grando, S., Maatougui, M., Michael, M., Slash, M., Haghparast, R., Rahmanian, M., Taheri, A., Al-Yassin, A., Benbelkacem, A., Labdi, M., Mimoun, H. and Nachit, M. (2010). Plant breeding and climate changes. Cambridge J ournal of Agriculture Science, 148: 627-637.

Eitzinger, J., Orlandini, S., Stefanski, R. and Naylor, R.E.L. (2010). Climate Change and agriculture: Introductory editorial. Cambridge J ournal of Agricultural Sciences, 148: 499-500.
Farrell, T. C., Fox, K. M., Williams, R. L. and Fukai, S. (2006). Genotypic variation for cold tolerance during reproductive development in rice: screening with cold air and cold water. Field Crop research, 98: 178-194.

IPCC (Inter-Governmental Panel on Climate Change) (2007). Climate change and its impacts in the near and long term under different scenarios. In Climate C hange 2007: Synthesis Report (Eds the Core Writing Team, R. K. Pachauri \& Reisinger), pp. 43-54. Geneva, Switzerland: IPCC.

IRRI (1976). Annual Report. Manila, The Philippines: IRRI

Kreye, C., Reversat, G., Fernadez, L., Vera Cruz, C., Elazegui, F., Llorca, L., Faronilo, L. and Bouman, B. (2007). Aerobic rice, a water-saving rice production system and the risk of yield failure - A case study from the Philippines in conference on International Agricultural Research for Development, University of Kassel - Witzenhausen and University of Gottinger, October, 2007, pp. 9-11.

Matsui, T., NAMuco, O. S., Ziska, L. H. and Horie, T. (1997a). Effects of high temperature and $\mathrm{CO}_{2}$ concentration on spikelet sterility in indica rice. Field $\mathrm{C}^{2}$ rops Research, 51: 213-219.

Nakagawa, H., Horie, T. and Matsui, T. (2003). Effects of climate change on rice production and adaptive technologies. In Rice Science. Innovations and impact for Livelihood. Proceedings of the Inter national Rice Research C onference, B eijing, China, 16-19 September 2002 (Eds T.W. Mew, D.S. Brar, S.Peng, D. Dawe and B. Hardy), pp. 635-658. Manila, The Philippines: IRRI.

Shah, F., Huang, J., Cui, K., Nie, L., Shah, T., Chen, C. and Wang, K. (2011). Impact of high temperature stress on rice plant and its traits related to tolerance. The J ournal of Agricultural Science, 149(5): 545-556.

Yin, X., Kroff, M. J. and Goudriann, J. (1996). Differential effects of day and night temperature on development to flowering in rice. Annals of B otany, 77: 203-213. 